\title{
ÉTICA COMERCIAL E INSTRUMENTOS ANALÍTICOS DE TEORÍA ECONÓMICA EN LA SUMA DE TRATOS Y CONTRATOS DE TOMÁS DE MERCADO
}

\author{
Eduardo Escartin-González. - Universidad de Sevilla \\ Dr. Francisco Velasco - Universidad de Sevilla \\ Dr. Luis González - Universidad de Sevilla
}

\section{RESUMO}

Este artigo divulga o pensamento econômico de Thomas de Mercado, Scholastic espanhol e aluno relevante da Escola de Salamanca nos economistas do século XVI. Ele escreveu Tratos y Contratos de Mercaderes y Tratantes (1569), cujo objetivo era alcançar práticas empresariais virtuosos e consistente com a doutrina cristã. Hoje em dia, quando o único objetivo da muitas empresas de lucro é fazer dinheiro sem olhar para quem foi atropelado, este trabalho tem completa hoje porque está faltando alguma coisa na ética comercial. Além de algumas pinceladas biográficas e dissertações do autor sobre a lei natural, os aspectos mais relevantes do pensamento econômico de Mercado são expostos, como: a propriedade privada; a intervenção pública ea superestrutura jurídica e religiosa; as atividades econômicas; a moralidade no comércio; o preço justo; a tributação, os instrumen tos analíticos, entre outros, o valor dos bens, o poder de compra do dinheiro, o tempo e a taxa de juros.

Palavras chaves: Escolástica, Escola de Salamanca, Economia, Ética, Pensamento Econômico.

\section{ABSTRACT}

This article disseminates the economic thought of Tomás de Mercado, Spanish scholastic and outstanding student of the School of Salamanca of economists in the sixteenth century. He wrote Tratos y Contratos de Mercaderes y Tratantes (1569), whose purpose was to virtuous business practices and make them consistent with the Christian doctrine. Nowadays, when the sole purpose of many for profit businesses is to make money without looking at who gets harmed, this work is very important because something of ethics is missing in trade. Apart from a few biographical brushstrokes and disquisitions of the author on natural law, the most relevant aspects of economic thought of Mercado are exposed, such as private property; public intervention and the legal and religious superstructure; economic activities; morality in trade; fair price; taxation; analytical tools, among others, the value of the goods, the purchasing power of money, the time and the interest rate. 
REVISTA CONVERGÊNCIA CRÍTICA

Dossiê: História Política

Keywords: Scholastic, School of Salamanca, Economics, Ethics, Economic Thought. Sevilla 31 de enero de 2014

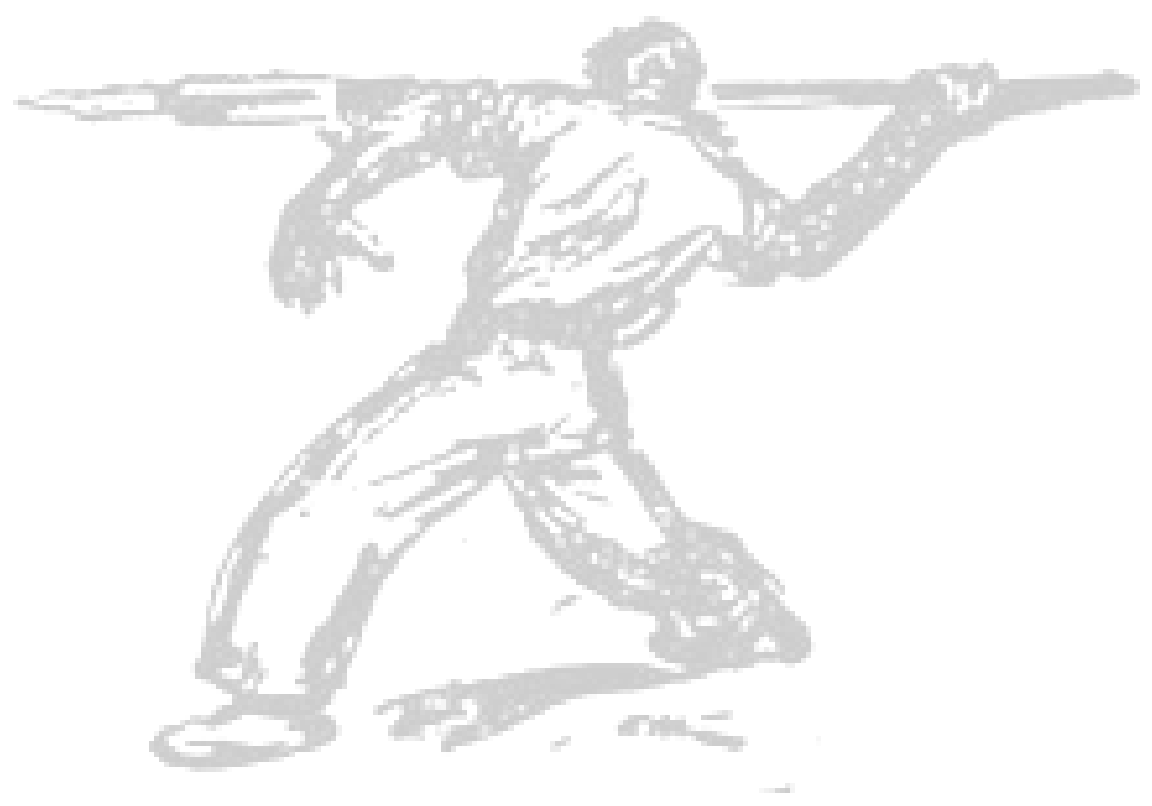

Núcleo de Pesquisa e Estudos em Teoria Social - NEPETES

2238-9288

49 


\section{ÉTICA COMERCIAL E INSTRUMENTOS ANALÍTICOS DE TEORÍA ECONÓMICA EN LA SUMA DE TRATOS Y CONTRATOS DE TOMÁS DE MERCADO}

1. INTRODUCCIÓN:

Tomás de Mercado es un autor del siglo XVI bastante conocido. En su tiempo fue un referente en cuestiones económicas, incluso tras las fronteras nacionales, perdurando su influencia en Europa hasta finales del siglo XVIII; luego cayó en el olvido del que fue rescatado en el siglo XX. Desde entonces se ha escrito mucho sobre su pensamiento; por ejemplo, en tres publicaciones recientes hay sendos artículos: uno de Jesús de la Iglesia (2012:41-44), otro de Manuel Martín (2012:37-44) y un tercero de Manuel J. Lagares (2013:71-95) ${ }^{1}$; también conviene destacar los espacios dedicados a Tomás de Mercado en la magna obra Dirigida por Fuentes Quintana, donde se incluye el ensayo de Sánchez-Albornoz (1999:243-247)². En nuestros días, cuando se está superando el lastre de desligar lo económico de lo moral, Tomás de Mercado cobra actualidad por haber sido un ejemplo del necesario vinculo entre la Economía y la Moral. Mercado es tan egregio que siempre dará pie a nuevos estudios. Sierra (1975:55) exhorta a efectuar un estudio monográfico, incluso una tesis doctoral, sobre la Suma de tratos y contratos. ${ }^{3}$ El presente artículo, sin llegar a tanto por las limitaciones de espacio editorial, presenta la novedad de añadir aspectos no incluidos en los escritos anteriores y, con esta intención, se divulgan plurales facetas del pensamiento de Tomás de Mercado.

\section{RESEÑA BIOGRÁFICA}

Hay pocos datos biográficos de Tomás de Mercado. No se conoce con exactitud ni el lugar ni la fecha de su nacimiento, que debió ser en Sevilla hacia 1530, y su fallecimiento en 1579, cuando regresaba a México desde la Península Ibérica. Sin embargo, otros autores fechan su nacimiento en 1523 en México, y su óbito en 1575 durante el citado viaje de regreso a su patria de adopción.

${ }^{1}$ Iglesia, Jesús de la: "El precio justo según Tomás de Mercado y Luis de Molina", Historia del Pensamiento Económico en España (siglos XVI al XX), Madrid, Editorial Complutense, 2012 (pp. 41-44).

Martín Rodríguez, Manuel: “Tomás de Mercado y su análisis de la economía andaluza: la Suma de Tratos y Contratos (1571), Historia del Pensamiento Económico en Andalucía, Granada, Editorial Comares, 2012 (37-44).

Lagares Calvo, Manuel J.: "Tomás de Mercado: La huella de un sevillano en el pensamiento económico actual", Economía y Economistas Andaluces, Dir. Rocío Sánchez Lissén, Madrid, Ecobook-Editorial del Economista, 2013 (pp. 71-95).

${ }^{2}$ Sánchez-Albornoz, Nicolás: "Entre la tradición escolástica y la práctica mercantil: Tomás de Mercado", Economía y Economistas Españoles, Dir. Enrique Fuentes Quintana, Barcelona, Círculo de Lectores, 1999, Vol. 2 (pp. 243-247).

3 Sierra Bravo, Restituto: "Estudio introductorio" a la Suma de tratos y contratos, Madrid, Editora Nacional, 1975 (pp. 7-64). 
Siendo muy joven sintió una profunda vocación religiosa que le llevó a tomar los hábitos en el Convento de Santo Domingo de la Ciudad de México, donde estudió teología, y se ordenó sacerdote en 1551, fecha discutida pues hay quien considera que fue en 1558. Inmediatamente después de su ordenación ingresó en la recién inaugurada Universidad de la capital virreinal de México, en la que estudió leyes y otras disciplinas. La presencia de Mercado en la Universidad de México, también es dudosa, pues algunos autores consideran que no estudió en este centro, sino que toda su formación tuvo lugar en el Convento de Santo Domingo. En cualquier caso, siguió los estudios con aplicación y aprovechamiento, destacándose entre los demás alumnos. Se graduó como maestro de Teología, y fue profesor en ese centro debido a sus elevados conocimientos. Por tal motivo fue enviado a la Universidad de Salamanca para completar y ampliar su formación hacia 1562 o 1563.

Ocupó el cargo de lector en el Convento de Santo Domingo de México, y tuvo una amplia actividad como confesor y estudioso de la realidad social y económica de la sociedad mexicana de su época. En estos años recopila importante información práctica y teórica, al estudiar a los economistas escolásticos a través de sus obras llegadas a la capital del virreinato.

Es considerado por algunos autores como el fundador de la Escuela de Economía Escolástica en México, que según Santos (1999: XXI), citando al profesor Oreste Popescu, fue muy importante en América puesto que tuvo ramificaciones en otros virreinatos ${ }^{4}$.

En la universidad de Salamanca profundizó sus estudios en los que se incluía el planteamiento iusnaturalista; allí obtuvo el grado de maestro en teología.

Mercado publicó en Salamanca en 1569 su obra fundamental, cuya primera edición se titulaba Tratos y Contratos de Mercaderes y Tratantes. Es probable que este estudio fuera iniciado en México antes a su venida a la península, como barrunta Popescu ${ }^{5}$. El libro fue muy bien recibido, y se reeditó en Sevilla en 1571 bajo el título Suma de tratos y contratos. Como todas las citas de Mercado se refieren a este libro sólo se indicará entre paréntesis el número de la página ${ }^{6}$.

Con posterioridad a la consecución de esa maestría en teología residió varios años en Sevilla, donde también impartió clases en su Universidad. En 1575, o 1579 según otras fuentes, se embarcó para México, sin saberse los motivos que le indujeron a ello. Finalizando el viaje encontró la muerte poco antes de llegar a San Juan de Ulúa (Veracruz) en la costa de Nueva España.

\section{LA LEY NATURAL}

\footnotetext{
${ }^{4}$ Santos Redondo, Manuel: “Álbum”, Economía y Economistas Españoles, Dir. Enrique Fuentes Quintana, Barcelona, Círculo de Lectores, 1999, Vol. 2 (p. XXI).

${ }^{5}$ Popescu, Oreste: "Contribuciones indianas para el desarrollo de la teoría cuantitativa del dinero", Economía y Economistas Españoles, Dir. Enrique Fuentes Quintana, Barcelona, Círculo de Lectores, 1999, Vol. 2 (p. 213).

${ }^{6}$ Mercado, Tomas de [1571]: Suma de Tratos y Contratos, edición de Restituto Sierra Bravo, Madrid, Editora Nacional, 1975.
} 
Tomás de Mercado basa la vida social y la económica del hombre en la ley natural. Quizás su concepción de ésta se inspirara en la doctrina expuesta por san Isidoro de Sevilla $^{7}$, ya que sus obras debieron ser de obligada consulta en la Universidad de Salamanca según se colige de las frecuentes citas que de él hace otro autor que, al igual que Mercado, estudió en dicha Universidad: Bartolomé de las Casas, en su Historia de las Indias. ${ }^{8}$ Una vez comprobaba la favorable acogida de su libro Tratos y Contratos de Mercaderes y Tratantes decidió ampliarlo adecuadamente y cambiarle el título y así aparece, entre los añadidos contenidos en la segunda edición de 1571: Suma de tratos y contratos, un primer libro introductorio que trata de la ley natural, porque dice Mercado (p.94) «es el fundamento en el hombre de todas las positivas».

Tomás de Mercado, en los tres capítulos dedicados a la ley natural, va dirigiendo razonadamente en las implicaciones de la ley natural sobre la actividad de los hombres y en su conducta. Para la mejor comprensión de la ley natural, sus explicaciones se remontan al origen de la creación, cuando Dios infundió un comportamiento característico a los animales según su propia naturaleza. Del siguiente modo expresa la idea Mercado (p.98): «los brutos animales se gobiernan por instinto natural [...] el instinto natural muestra a los brutos lo que han de hacer».

Para Mercado, la ley natural gobierna todas las cosas y rige su comportamiento según su propia naturaleza, «y se llama juntamente ley divina» por emanar de Dios (p.100). Al hombre le sucede lo mismo, que está presidido por la ley natural, o sea por la ley de Dios: «De manera que ésta es nuestra lumbre, y nuestra guía y regla: que puso Dios en el alma para que la siguiéramos» (p.98). Empero, Dios no creó al hombre igual que a los animales; le dotó de libre albedrío y de razón para que ésta «le enseñase lo que debía hacer o dejar: más dejándolo libre conforme a su natural, para que lo haga si quiere» (p.98). Es decir, el hombre es libre por naturaleza y su comportamiento no es único, como el de los animales que está regulado por el instinto. El hombre tiene capacidad para elegir, entre diversas alternativas, un modo concreto de actuación. El problema consiste en que su opción se ajuste a la ley natural, y para ello, para no equivocarse, cuenta el hombre con la razón, la cual descubre, según las pistas e indicios que Dios establece, un comportamiento que no vulnere la ley natural. La primera manifestación de ésta es que el hombre tiene que vivir, y, incluso vivir bien. Mas los humanos no están dotados por naturaleza de la capacidad suficiente para satisfacer sus necesidades vitales, subsistir y procrear individualmente. Después de crear Dios a Adán le concedió una esposa, Eva, y, recuerda Mercado (p.127), les dijo: «creced y multiplicad, henchid la tierra, y enseñoreados de ella aun hasta de los peces de la mar, y de las aves de la

\footnotetext{
${ }^{7}$ Isidoro de Sevilla (san): Etimologías; edición bilingüe, Madrid: Biblioteca de Autores Cristianos, 2000. Dice san Isidoro (Et. Lib. V, 2, 1, Vol. I:511): «las leyes divinas tienen su fundamento en la naturaleza».

${ }^{8}$ Casas, Bartolomé de las: Historia de las Indias, Caracas: Biblioteca Ayacucho, 1956. Por ejemplo, en Lib. I, Cap. 15: 80; Lib. I, Cap. 16: 85; Lib. I, Cap. 20: 113; Lib. I, Cap. 128: 511; etc.
} 
tierra» ${ }^{9}$. Por tanto el hombre tiene necesidad y está inclinado por su natural «a vivir en compañía de muchos dispuestos en república. Porque no hay persona alguna que no tenga necesidad, y haya menester el favor de muchos, para poder bien vivir en esta vida [...] la razón provee lo necesario a semejante vida política (conviene a saber) que este modo de vivir en congregación (pues como dice el filósofo) es para bien de todos, y [...] no sea a nadie dañoso, sino a todos provechoso» (p.110).

Así pues, para Mercado (p.110), «entre los primeros principios naturales uno de ellos es: hacer a otros el bien, que para ti propio querrías ${ }^{10}$. Y el otro negativo, no hacer, lo que holgarías que nadie hiciese contigo». Este principio tiene gran importancia porque de él se derivan dos virtudes «que son la justicia, y la misericordia. La justicia, para no agraviar, la misericordia para beneficiar» (p. 110). Estas virtudes son básicas para la convivencia humana en sociedad, pues «lo primero (que es a nadie agraviar) es siempre de obligación. Lo segundo (que es hacer bien) unas veces es voluntario, otras de precepto» (p.110). Por ello, los actos buenos para cada cual no deben a nadie perjudicar. Esto es tan elemental que todos pueden comprenderlo fácilmente, pues fue Dios «quien escribió en nuestros corazones [...] que no hiciésemos a otros el mal que no querríamos para nos» (p.101). Esto es tan obvio que no se precisa recurrir a los demás, a sus enseñanzas, ni siquiera al estudio de los libros, pues cualquiera que se pregunte si querría que le robasen el dinero, o el trigo, o el ganado por sí mismo respondería que esto está mal. Por tanto también «entiende, que tampoco debe hacer a otro ninguno de estos males» (p.102). De este principio se desprende que las personas deben tratarse con justicia, es decir, con «igualdad y equidad en los contratos» (p.112).

La dificultad de hacer justicia estriba en que se deben «ajustar dos cosas disímiles» (p.111). Sin embargo, en la mayoría de los casos, es más sencillo y suficiente averiguar sólo si hay agravio para descubrir si en el contrato hay desigualdad, y, por consiguiente, injusticia (p.112). Dejando aparte la forma de hacer justicia que corresponde a los jueces, Mercado en toda su obra se dedica a estudiar otra suerte de hacer justicia: la conmutativa, perteneciente a las relaciones humanas de intercambio. Tal justicia «se ejercita, y resplandece principalmente en los contratos que entre sí los hombres unos con otros celebran» (p.115). En virtud de esta justicia conmutativa (no agraviar a otros mediante la desigualdad entre la prestación y la contraprestación en los contratos), la estrella polar que siempre guiará a Mercado (p.115) será el precio justo, «según el juicio del pueblo», que se puede juzgar ilícito cuando manifiestamente no se «iguale lo que se trata en estima y precio» por ambas partes. A modo de resumen se transcriben las siguientes palabras de Mercado (p.116-117):

En los cambios reales, do para interesar algo, es necesario ser desiguales en cantidad la saca, y pagamento: todo el acertar consiste en ajustar en estima, lo que en cantidad y

\footnotetext{
${ }^{9}$ Gen. 1,28.

${ }^{10}$ Esto equivale a la regla de oro recomendada por Jesucristo: omnia quaecumque vultis ut faciant vobis homines et vos facite eis (haz a los demás lo que quieras que los demás te hagan (Mt. 7:12).
} 
número es desigual. Y toda la injusticia, es ser en todo desiguales, los dineros que se dan y se reciben. De arte, que la justicia en todos los contratos, es la igualdad, que en ellos se ha de hacer [...]. Y es suficientísima causa para reprobar algún negocio, por de gran interés que sea, no ser conforme al recto dictamen de la razón. [...]. De lo cual se deduce, cuánto yerran los hombres, que para tener cualquier contrato en particular, por lícito: o al menos por ilícito, quieren que les traiga texto formal y redondo sagrado, do lo condena Dios [...]. Lo primero digo a éstos, que la ley divina es la razón acertada, pues Dios como enseñamos por ley, y regla nos la dio. A cuya causa nos explica en su escritura, todas las cosas morales en singular. Porque ya nos ha dado desde el principio, la lumbre natural, que nos enseñe y encamine, lo que fuere justicia y razón [...]. Persuadiendo lo recto y justo, o disuadiendo lo contrario.

Un punto oscuro, desde la perspectiva actual, se observa en las concepciones de Mercado; se trata de sus consideraciones sobre la esclavitud de negros e indios. A este respecto, Mercado no cuestionó las apreciaciones aristotélicas y tomistas dominantes entre los teólogos de su época. Respecto de los indios admite Mercado (p.276) el tópico propagado en su tiempo sobre la condición de los indígenas americanos: "son viciosos y bárbaros, cometen enormes y detestables delitos, por los cuales según sus leyes, lícitamente se cautivan y venden". Y eso que el primer obispo de Chiapas (Mexico), Bartolomé de las Casas, a quien Mercado, por ser de su misma Orden de Predicadores (dominicos), debió de conocer, al menos de oídas, ya había defendido a los indios denodadamente, con actos y por escrito. De ellos dice Las Casas: son "pacíficos, humildes y mansos que a nadie ofenden"; y de los habitantes del Yucatán comenta: "La gente dél era señalada de entre todas las de las Indias, así en prudencia y policía como en carecer de vicios y pecados más que otra" ${ }^{\prime 1}$.

No obstante, asumido el principio ético de no incurrir en los tratos en fuerza o dolo, aprecia Mercado (p. 280) ser doctrina cierta "que cuando constare de la violencia, o engaño, que se les ha hecho [al esclavizarles], se les restituya perfectamente su libertad".

\section{LA PROPIEDAD PRIVADA}

Según Mercado (p.117), al principio de la humanidad regía la propiedad comunal, «de tal modo, que todo fuera de uno y todo de todos. Y no había cosa, que cualquiera no pudiera usar, servirse, y aprovecharse». El origen de la propiedad privada se halla en el pecado de los hombres; y por eso se perdieron las condiciones y virtudes que los predisponían para convivir sin ser necesario distinguir entre lo mío y lo tuyo en una «comunidad tan excelente y divina» (p.127). Así es que se hizo preciso repartir por partes, «aplicándose a cada uno la suya como legítima herencia: y tuvo principio y origen la propiedad y comenzóse a introducir este lenguaje tan común de mío y tuyo» (p.127).

Las condiciones que antaño justificaban la propiedad común eran:

${ }^{11}$ Las Casas, Bartolomé, de [1555]: Brevísima relación de la destrucción de las Indias, Madrid, Alianza Editorial, 2010 (p. 68 y p. 121, respectivamente) 
$1^{\circ}$. No tener apego a las necesidades personales. Primaba la necesidad colectiva y nadie tenía extrema necesidad de algo. La extrema necesidad no tiene ley. Ante el padecimiento del hambre no es condenable tomar «lo que ha menester» (p.128), pero solo si los hombres son verdaderamente frugales, de modo que «sin manjar y comida que realmente habían menester, se podía pasar, y sufrir muchos días» (p.128). Al contrario, transcurridos esos tiempos antiguos, la división y la partición en propiedades privadas se impuso debido a la flaqueza y miseria de ánimo. La propiedad privada quedó justificada en lo siguiente: «Agora estamos tan sujetos a estas temporalidades, y tenemos tantas necesidades, que es menester que cada uno tenga su hacienda poca o mucha para que sepa de qué se ha de valer en ellas, y deje la ajena de qué se valga su dueño» (p.128).

$2^{\circ}$. No amar para sí las cosas. Primaba no tener apetitos desorbitados de bienes y riquezas. En cambio, cuando se ha pasado a usar las cosas ajenas atesorándolas para sí y «en nosotros ha crecido tanto su codicia» (según cita de Séneca que hace Mercado, en p.128) queda justificada la propiedad privada como algo natural, para preservar lo propio del deseo ilimitado de los demás (p.128-129).

$3^{\circ}$. Buscar y promover lo que toca a la comunidad. Esta condición precisa que todos procuren con diligencia las cosas comunes, que las aumenten y conserven en beneficio de la comunidad, «estimando y teniendo en más el bien común que el particular» (p.129). Empero, se ha llegado a una situación en la que, según dice Aristóteles (a quien Mercado cita, p.129) «se ama más una cosa cuando se tiene por propia» y «ahora no hay quien no pretenda su interés: y quien no cuide más de proveer su casa, que la república. Así vemos que las haciendas particulares van adelante, y crecen: las de la ciudad, y consejo, se disminuyen: son mal proveídas y peor regidas». Cuando se llega a tal situación, la propiedad privada queda justificada, según Mercado (p.129) citando a Aristóteles, en:

el deleite que el hombre recibe, de ocuparse en sus negocios propios. No se puede fácilmente explicar cuanto hace al caso, para hacer una cosa con alegría, considerar el hombre que es suya. Al contrario es gran tibieza la con que trata negocios comunes. De modo que perdida aquella primera caridad, fue necesario que cada uno tuviese alguna parte en las temporalidades, en raíces, o en muebles: para que ya que no el amor universal, a lo menos el particular interés le moviese a conservarlo.

En resumen, aunque la propiedad privada no es de origen divino, sino humano y asentada en el pecado, se llega a un punto en la evolución de las sociedades en que se impone la institución de la propiedad privada como algo necesario, pero regulable por la autoridad pública, para evitar males peores debidos a la codicia de los hombres y para estimular que la comunidad disponga de más bienes a pesar de que unos pocos obtengan un mayor beneficio privado. Entonces, la propiedad privada ya no se cuestiona; se intenta que de ella no se deriven injusticias flagrantes. Y no sólo no es cuestionada la propiedad privada, sino que en ella se encuentra el origen del valor y precio de las cosas: sin propiedad privada no existiría el precio. Mercado (p.160) opina: 
Demás desto certísimo es, que todos están obligados a vender cada cosa por lo que vale. Esto es un dictamen natural de la razón que sin doctor ninguno, ni ley positiva lo enseña a todas las naciones. Mas cuál sea justo precio de cada una, la naturaleza no lo tasa ni señala. Ella las crío y produjo, mas no las apreció. Por qué a la verdad no las crío para que se vendiesen ni enajenasen: sino para que como de todos a todos sirviesen [...]. Nuestra malicia las hizo particulares, y nuestra necesidad venales.

En la propiedad privada también se encuentra el origen del comercio pues en el reparto a unos tocó cierta clase de bienes y otra diferente a otros. De forma que tuvieron unos y otros, al no ser autosuficientes, necesidad de intercambiar sus respectivos bienes. Inicialmente se utilizó el trueque como forma de intercambio y después se empleó un bien como intermediario: el dinero; más tarde el comercio se extendió a lugares lejanos, por un motivo similar al anterior, porque no en todos los sitios había de todo. Incluso en el arte del mercader se encontraba el evaluar los bienes que podrían servir a otros hombres y llevarlos allí donde podrían serles útiles (Mercado, p.129-130).

\section{LA INTERVENCIÓN PÚBLICA Y LA SUPERESTRUCTURA JURÍDICA Y RELIGIOSA}

Mercado dice (p.110), al ser de ley natural que los hombres han de vivir en congregación para ayudarse mutuamente a satisfacer sus necesidades, que la vida comunal «es para bien de todos», el cual es el fin principal de la república, a la cual «le pertenece promover toda la utilidad y provecho de los vecinos» (p.155). A ello contribuye el comercio, que, en su origen, fue una actividad muy estimada por las gentes por «la gran comodidad y provecho que causa [...] en todo el cuerpo de la república» (p.132), al proveer a «las ciudades y reinos de infinita variedad de cosas que ellos en sí no tienen, trayéndolas de fuera»; por la contribución de los comerciantes a la difusión cultural entre los pueblos con los que establecían tratos, o sea: «Son útiles a su república, por la gran noticia de varias cosas que han visto y oído en su peregrinación» (p.133); y por haber «mercaderes varones muy excelentes que con su prudencia y potencia escaparon muchas veces su patria de grandes males en tiempos muy peligrosos, y aún edificaron ciudades muy populosas y ricas» (p.133). No obstante lo que se acaba de referir, llegó un tiempo en que la finalidad principal de los mercaderes pasó a ser la acumulación de oro y plata en provecho propio y «no el conocimiento y noticia de las gentes y ciudades (cosa conforme a la razón muy preciada)»; por este motivo, concluye Mercado (p.133):

vino el arte [del comercio] justamente a ser en poco tenido y a ser [...] afrentoso su ejercicio y uso. Porque ya el ser mercader, no es ser hombre deseoso del bien de su patria como antes, sino muy amante de su dinero, y codicioso del ajeno: vicio, que a los hombres de buen ingenio dio siempre muy en rostro. En este grado está el presente trato según prueba manifiestamente el común juicio del pueblo.

Surge así una pugna entre los intereses públicos y los privados, porque «el deseo del mercader es el universal de todos, [...] querer mercar barato, y vender caro, y tiene más 
el tratante: que no solo lo desea y apetece si no lo ejercita y procura ${ }^{12}$. El deseo de la república es que se venda lo más barato que se pudiere» (p.155). Puesto que existe este conflicto de intereses, la república tiene la potestad y la autoridad legítima de intervenir en los negocios privados para procurar el bien común. Entre las intervenciones lícitas de la autoridad pública Mercado (p.155-161) destaca tres clases:

$1^{a}$. Expulsar a los mercaderes extranjeros, porque, además de ser licenciosos y sembradores de abusos y vicios, expolian a la república llevándose a la suya las ganancias. La república, en cambio, debe fomentar que el comercio sea ejercido por los naturales del país.

$2^{a}$ Reservar para sí la traída, entrada, y venta de algunas mercancías que especialmente sean beneficiosas para la comunidad. Aunque la república, en aras del bien común, pudiera hacerlo con todo tipo de mercancías, no debe mirar sí puede o no hacerlo, sino si es conveniente que lo haga. En bastantes ocasiones no se precisa tomar tan drástica medida; es suficiente tasar el precio de venta de las mercancías muy necesarias e indispensables para la comunidad, sin las cuales no se puede vivir, porque dejando al mercader la libertad de fijar el precio de esos bienes tan necesarios sería lo mismo que concederle una patente para robar a la comunidad (p.157). O sea, el poder público debe impedir que los vendedores esquilmen el bolsillo de los consumidores para que no merme su poder adquisitivo en otros productos.

$3^{\text {a }}$. Establecer y promulgar leyes que regulen los contratos para lograr la justicia conmutativa; tasar las cosas que, sin ser estrictamente necesarias para la vida humana, ayuden en los negocios, como fijar el valor del dinero; e incluso tasar el valor de las cosas necesarias: «Pues si la naturaleza no tasa cuánto han de valor, cuántos reales, cuántos ducados: a quien más conforme a razón pertenecerá proveer esto, siendo tan necesario, es a la república; cuyo oficio es suplir con sus ordenaciones lo que la naturaleza falta» (p.160).

Pese a lo anterior, Tomás de Mercado y los escolásticos fueron en esencia liberales, pues, en su opinión, el soberano, aun pudiendo intervenir en los asuntos económicos, debe mirar muy bien si es apropiado que lo haga. Dice Mercado (p.157): «no debe mirar el príncipe sólo si puede hacer una cosa, sino si conviene hacerla. Y hallará muchas veces, lo que el apóstol [san Pablo] hallaba, que de muchas que pueden pocas convienen». Así ocurre si los bienes no son estrictamente necesarios para vida y no hay urgencia en la compra o la venta, en cuyo caso debía regir el principio de libertad de concierto en los tratos. A tal respecto opina Mercado (p.201): «Más si dos (a ninguno de los cuales compeliese necesidad) sino que libre y liberalmente dijesen concertémonos, agora valga allá lo que valiere. Válido sería el concierto, siendo como dije, libérrimo sin necesidad urgente, que de la venta o compra las partes tuviesen». Y también dice

${ }^{12}$ Esta apreciación coincide con el denominado principio de las ventajas absolutas del comercio, ya expuesto por Séneca, De los beneficios (Lib. VI; XXXVIII): la intención de todo comerciante es «vender caro, [y] comprar a precio cómodo lo que quería revender». 
Mercado (p.150) que: «Habiendo en un contrato de una parte y de otra opiniones buenas entre doctos: cada uno es libre para seguir la que escogiere», «porque la venta ha de ser libre de entrambas partes» (p.179). No obstante esta libertad genérica del trato, pueden sobrevenir causas suficientes para la intervención pública. Una de esas circunstancias sería cuando una de las partes llegara a saber que existía una gran desproporción entre lo entregado y lo recibido. Para apreciar eso, Mercado remite a un antiquísimo principio, que data de los tiempos de Diocleciano y Máximo. Estos Césares promulgaron una ley, que prohibía deshacer una venta y compra «si el precio no excediese en más o en menos de la mitad del justo valor»(p.201). Laesio enormis es el nombre por el que se conoce esta ley romana. Las reclamaciones al amparo de esta ley debían hacerse antes de transcurrir cuatro años desde la celebración del contrato de cambio o venta (p.202). Por otra parte el margen, aparentemente tan amplio, para efectuar la reclamación se debió a que el legislador pretendió evitar la multitud de pleitos que se originarían de ser menor el margen, dada la propensión humana a la codicia, a la malicia y al engaño (p.203). El amplio margen también estaba fundando en la gran dificultad de conocer con exactitud el justo precio de las cosas sin tasa; cuando la hay no rige esta ley pues cualquier desviación del precio fijado legalmente es reclamable. Si en fijar el precio contractual hubieran intervenido apreciadores públicos, o se establecieron en subastas públicas, no sería aplicable dicha ley (p.202).

He aquí un ejemplo de cómo el sistema jurídico contribuye a que los intercambios no sean tan exageradamente desiguales, evitando que tal iniquidad provoque el malestar de la gente; y a la vez evite la saturación de pleitos en los tribunales. Pero es más, Mercado (p.170) consideró que la religión y sus ministros, los sacerdotes, también han de cumplir una función similar colaborando en el mantenimiento de la «disciplina política y ciudadana» en la república. La moral religiosa es un complemento de la ética legal, pues aprecia injusta cualquier separación del precio justo, sin llegar a las desviaciones de la ley positiva en más o menos del 50\%: «De cualquier modo que se exceda o falte, y no llegue al precio que señalemos es la venta injusta», asevera Mercado (p.203) y añade: «De manera que siendo el exceso, o falta menor será el contrato ilícito, en ley natural y divina, pero la civil aunque le parece mal y querría que siempre se diese cada cosa por lo que vale, no quiso que se tratase de su injusticia en los estados».

La moral religiosa, a través de las conciencias, impele a muchos ciudadanos motu proprio a no agraviar a sus convecinos, o, si les dañan con un trato desigual, a restituirles el exceso o falta del precio justo, sin necesidad de dirimir la diferencia en los tribunales (a los que no se podría acudir si no se hubiera alcanzado el límite del 50\% establecido por el principio de la laesio enormis).

El papel que a este respecto juegan los sacerdotes y el sacramento de la confesión, Tomás de Mercado (p.170-171) lo juzgaba del siguiente modo:

Que para buen gobierno temporal de la república no hay cosa que más se requiera y aproveche, que buenos confesores [...]. Cosa importantísima, aun para la observancia exterior de la justicia. Porque remedian muchos daños, deshacen grandes agravios, imposibilitados a deshacerse por otra vía, impiden no pocos males, son causas 
continuamente de bien, no sólo espiritual, sino común y corporal. Las deudas: que no se pueden averiguar en juicio, las hacen restituir: la fama, que aún no sabía el otro, quién se la había quitado, y robado, se la hacen volver, haciendo al murmurador se desdiga [...]. Porque como no puede permanecer, ni aun comenzar república sin juez, y cabeza, así el juez, ni jueces por muchos que sean, la podrán bien gobernar sin confesores.

Es la confesión podadera, y hoz con que se cortan los vicios y crecen las virtudes: es un freno del alma y apetito. $Y$ es tan menester para que se viva en quietud y sujeción, tener enfrenada y temer la conciencia que la gente, que no la teme, está muy presta para no obedecer a sus superiores. Así que les es a los gobernadores del pueblo importante este sacramento, para conseguir su fin e intento, que es la obediencia y vida pacífica de los ciudadanos. Lo cual sin este medio, y remedio divino, no pudieran alcanzar, ni pudieran averiguarse con tantos, rigiéndolos por largo tiempo en justicia, equidad y blandura.

Un poco más adelante, Mercado (p.173) añade:

Que uno de los grandes cargos, que tiene el confesor, es dar a entender al penitente, cuánto importa a nuestra salvación, obedecer como dice el evangelio, los vasallos a sus príncipes, pagarles sus tributos; y pechos, responder sencillamente a su juez, que procede, y pregunta conforme a derecho, declararles cómo están en lugar de Dios. Cuanto al gobierno corporal, necesitarlos a que guarden sus estatutos, ordenanzas, tasas, y posturas. Cosas que si no se las predicase, y mostrarse el confesor: no las estimaría. Porque la gente común no siente, ni entiende la virtud, y obligación de las leyes civiles, sino en la confesión, ni las estima en conciencia (dejada la pena aparte) en más de lo que el confesor se las pone, y según se ve que por ellas pregunta, y procede en la administración de su sacramento.

Y, al fin, Mercado (p.174) concluye:

Volviendo a nuestro propósito, digo que deberían ser los padres confesores, muy padres de la república, pues son los principales gobernadores della, y la guarda principal de todo su bien, y el más fuerte amparo contra todo mal verdadero, que es el vicio, en hacer guardar a los penitentes sus leyes y ordenanzas. Dado que no hay menos obligación en los príncipes y en los que gobiernan, de ser rectos prestos y prudentes en tasar los precios, de modo que gane alguna cosa en su trato, quien sirve a la republica.

En resumen, para Mercado el principio general a aplicar en los tratos es el de la libertad entre las partes. Únicamente recurre a la intervención pública para evitar que una de las partes pueda salir perjudicada por la otra. En el caso de productos de primerísima necesidad los poderes públicos deben actuar directamente fijando los precios, y en el caso de los demás bienes se deja al poder judicial la solución de los conflictos en que alguien resulte damnificado, o bien a la acción de la propia moralidad de los individuos dirigida por el estamento clerical.

\section{LAS ACTIVIDADES ECONÓMICAS}

Tomás de Mercado (p.131) clasifica indirectamente en dos grandes grupos las actividades económicas. Todo lo que los hombres necesitan se obtiene, o bien transformando las cosas que hay en la naturaleza (cometido de la actividad productiva), o bien trasladándolas en el tiempo o en el espacio sin introducir en las cosas ninguna 
modificación. La segunda de estas actividades constituye el comercio, y los hombres que lo ejercen se llaman mercaderes. Así es que Tomás de Mercado no se molesta en establecer categorías dentro de la actividad genérica del comercio, como hizo Platón (1988:59) al clasificar en tres tipos la actividad comercial $^{13}$ : comerciantes, los encargados de traer y llevar los productos de (o, a) países lejanos, o sea, los que se dedicaban a exportar o importar mercaderías; traficantes, quienes hacían eso mismo, pero viajando de ciudad en ciudad por la república; y mercaderes, los que se dedicaban a la compra y venta en la plaza pública ${ }^{14}$. Para Mercado (p.131) el arte y profesión de los mercaderes:

es mercar la ropa por junto, y sin que se mude en otra especie, o se mejore en la suya, revenderla por menudo, o traerla fuera de la ciudad, o llevarla a otra parte del reino, o a otro reino. El mercader no busca, ni aguarda se mude la sustancia o cualidad de su ropa, sino el tiempo, y con el tiempo el precio o el lugar. ${ }^{15}$

Desde luego resulta muy curiosa esta definición del comercio porque equivale a que el tiempo es un destacado factor de la producción y fuente de la plusvalía en la actividad comercial. Este es un logro analítico de primera magnitud que Mercado utiliza en varias ocasiones, como por ejemplo cuando dice (p.141): «Hay otro género de ventas que es mercar alguna ropa: como fardos, o pipas de vino, o aceite, para llevarlas a otras partes, o aguardando otros tiempos, revenderlo por más de lo que costó. Entender y vivir de esto (como dice la ley) es ser mercader».

Mercado no se quedó en la trivialidad de una observación sino que la aplicó con carácter de generalidad a otros fenómenos económicos, como, por ejemplo, el de interés (a pesar de su condena hacia la usura) cuando indica que «este es precio del esperar la paga» (p.218).

Las restantes actividades económicas se caracterizan por la transformación, muy variada de las cosas; y aunque antes de ser modificadas también se compran esas cosas para después venderlas, una vez consumada la alteración, estas ventas no constituyen el comercio, ni los hombres que a ello se dedican son mercaderes. Serán labradores si compran trigo para sembrarlo y después de la cosecha venderlo; ganadero sería quien compara potros para hacer de ellos caballos y venderlos; vinatero quien compra mosto, para luego convertirlo en vino y venderlo (p.131). Evidentemente la producción implica tiempo. En cambio, el mercader no pretende transformar las cosas, sino solo esperar (porque con ello se aumenta el valor) o trasladar de lugar (porque así también se logra más valor) para vender exactamente el mismo objeto de compró (p.132).

En definitiva, hay dos formas de comprar y vender (p.141): Una para proveer las necesidades familiares y atender el consumo, y otra para ganar algo que constituye la

${ }^{13}$ Platon: La Republica, Barcelona, Editorial Iberia, 1988.

${ }^{14}$ No obstante, una clasificación similar a esta Mercado (p.137) la atribuye a Aristóteles (La Política, Barcelona: Editorial Iberia, 1967 (Lib. I, cap IV,2, p.24).

${ }^{15}$ En nota del editor al pie de la página 124 se comenta que Mercado utiliza la palabra «ropa» con doble acepción: unas veces significa vestido, y otras tiene la significación amplia y genérica de mercancía. 
actividad del mercader.

\section{LA MORALIDAD EN EL COMERCIO}

Nadie puede negar, ni a nadie puede sorprender, que «el intento común del tratante, es aumentar su caudal negociando», dice Mercado (p.135-136) siguiendo a Aristóteles. Al fin y al cabo casi todo el mundo pretende aumentar su fortuna mediante el ejercicio de su profesión. La cuestión estriba en dilucidar si esto es lícito (o no) y si los métodos adoptados para ello también lo son. En principio, Mercado (p.137) dice que la actividad del comercio en si es indiferente, como lo son muchos actos y aficiones de los hombres. Mercado (p.135) clasifica estos actos y aficiones de los hombres en buenos, malos, e indiferentes. Ejemplos de los buenos serían amar a Dios, u honrar a los padres. Entre los malos se encontrarían el mentir, o el robar. E indiferentes serían el hablar, el pasear o el vestirse. De estos últimos, por sí mismos, Mercado (p.135) dice:

ni suenan virtud ni vicio, sino que si se hicieren a buen fin, serán buenos; si a malo, malas y viciosas. Pero entre éstas, que están a modo de decir, en el medio indiferentes, hay algunas que se llegan (a lo menos en apariencia) más a un extremo que a otro. Unas tienen más disposición para la rectitud y justicia, que para el pecado y culpa.

Pues bien, la condición y el modo de vida de los mercaderes se ajusta más a este último extremo, ya que han de «de ir a la continua nadando contracorriente» en las aguas de la codicia (p.137). A este respecto, de los comerciantes comenta Mercado (p.136) que con el ejercicio de su profesión:

se le descubren y ofrecen en cada momento mil medios para ganar, e interesar, y los más de ellos peligrosos y pegajosos: y requeríase mayor virtud que la que ellos profesan y tienen, para andar en pie, y no caer en las ocasiones. A cuya causa se sospecha, que o malicia, o flaqueza, caen a la continua y anden siempre caídos.

Por eso no es de extrañar que el pueblo, no ya sospeche, sino crea que la fortuna de los mercaderes se amase con la injusticia y merezca su reprobación e incluso odio ${ }^{16}$. Pero, pese a todo esto, Mercado considera que la actividad del comercio es útil para la república y que los mercaderes tienen derecho a ganar su salario, por lo cual no hay que persuadirles a que abandonen su profesión, sino a que la ejerciten con licitud y justicia. Por eso Mercado (p.138) propone:

Así que enmiéndense y corríjanse los cristianos, y no sean mercaderes. Más dirásme que provees la república de muchos bastimentos, en que si algo ganas vendiendo más caro que compraste: es como estipendio y salario de tu trabajo, según está escrito en el evangelio, digno es el obrero de su jornal. Si miento y juro: vicios y pecados son míos: no del arte, que muy bien se podría ejercitar si yo quisiese sin mentir, ni jurar. Esto me amonesta y persuade: no que deje de ser mercader, sino que deje de ser mentiroso y perjuro.

De las dos formas de comprar y vender (mencionadas en el apartado anterior), la primera, por su propia finalidad (que es la de atender al sustento familiar), constituye

${ }^{16}$ Aproximadamente esta es la opinión que expresa Mercado (p. 133), según la cita que de él se hizo anteriormente, en el epígrafe LA INTERVENCION PUBLICA. 
una actividad perfectamente natural y lícita. En cambio, no se puede afirmar tajantemente lo mismo de la segunda, que consiste en revender las cosas por más de lo que costó. «Y a este tal [tipo de venta] les buscamos algún buen fin, para que lo haga bueno: que al otro no es menester buscárselo, que él lo tiene de suyo santísimo» (p.141). La primera justificación es que el tratante tenga recta intención, y, además, de entre los fines buenos que puede tener, Mercado (p.142) señala el de aprovisionar a la república de las cosas necesarias para la vida humana, atendiendo al bien común: «el más propio es que pretenda proveer la república de los bastimentos, ropa o mercerías, que le faltan [...]. Con este intento sería su trato de gran mérito ante Dios, y muy ahidalgado entre las gentes. Porque ningún caballero se desdeñaría de hacer esto por su república, antes se preciaría (caso fuese menester)». La recta intención es fácilmente comprobable, pues, como dice Mercado (1975:142):

el que pone los ojos en servir a la república en este trato, no le pesa haya abundancia de mercaderías, ni baje el precio (como él no pierda) aunque entonces no gane. Y que do ve que no puede interesar mucho: no la guarda para cuándo se acaba y consuma, como acaece en los de aquí y en los de allá, de que podríamos hablar largo aun de vista.

La segunda justificación es la que ya había señalado santo Tomás de Aquino: la práctica de la caridad, para socorrer al menesteroso, pues con la limosna se remedian necesidades ajenas. Mercado (p.142) considera que:

Celo es sapientísimo este apostólico [se refiere a San Pablo], caridad viva y hervorosa: que los mismos pobres mantengan otros de su mismo trabajo y sudor. Mucho menos es lo que a los mercaderes manda este sacro doctor, en que tengan por fin de sus ganancias, dar limosna, pues se entiende, sacando primero para sí una holgada pasadía. Mas no hay ya tanta virtud en la gente, ni me quiero más detener en exponer la excelencia, valor y mérito deste fin, que sería hablar con sordos, o llover palabras en desierto: que ninguna se oiría.

Y la tercera justificación (que en realidad ya ha sido mencionada supra) es que el mercader debe obtener una moderada ganancia para mantener los gastos de su casa y su familia conforme a su condición. Pero en la opinión de Mercado (p.143-144) esta última justificación es la de menor importancia, y, sin embargo, de estos tres fines del comercio, los mercaderes:

hacen más caso del postrero (que es ínfimo) que del primero y segundo, tan soberanos. Y no sólo con gran desvarío lo prefieren, más a este solo siguen, y a este solo pretenden, olvidándose totalmente de los otros, como si fueran criaturas faltas de conocimiento, formadas para servicio de su vientre, o como si el lustre y prosperidad aparente desta vida fuese la verdadera felicidad humana que buscamos.

Mercado (p.144) no deja de observar que todavía existe un cuarto fin, que es el que tienen por principal los mercaderes (con desprecio de los tres anteriores y por supuesto reprobable desde el punto de vista de la moralidad), a saber: el afán de enriquecimiento a «buscar con daño y agravio de todos». Y recordando las palabras de Aristóteles y de san Pablo dice (p.144): «que ningún término tiene el mercader en atesorar dinero y ajuntar posesiones, porque con el peso de su codicia ha caído en el lazo y tentación del 
Demonio, do dice el Apóstol, que suelen caer los que quieren enriquecer».

Tomás de Mercado (p.147-153) se permite la siguiente licencia: «dar a estos señores algunos buenos consejos, tales, que si los tomaren y siguieren, ya que no ganen gran hacienda, ganaren con ellos (a mi parecer) una gran reputación y buena opinión en el pueblo y excusaran muchos gastos dañosos a la bolsa y no muy honrosos a la persona». Estos buenos consejos que Mercado receta son:

$1^{\circ}$. Que no lleven un género de vida ostentoso, para que las gentes del pueblo no sospechen haber sido engañadas en mucho. ${ }^{17}$

$2^{\circ}$. Que sean comedidos y parcos en el hablar, para que no se piense de ellos que con las muchas palabras pretenden enredar y engañar a la gente.

$3^{\circ}$. Que se abstengan de jurar, para que no caigan en perjurio.

$4^{\circ}$. Que sean caritativos, para que con la limosna puedan descargarse de los abusos que cometieren al cobrar más del justo precio.

$5^{\circ}$. Que se aficionen a la lectura de buenos libros, para que con su lección aprendan a ser virtuosos.

$6^{\circ}$. Que vayan asiduamente a misa, para que saquen buen fruto de este sacramento.

$7^{\circ}$. Que elijan un buen confesor, de ciencia y conciencia, docto y versado en la práctica de los negocios.

\section{EL PRECIO JUSTO}

La consecución del bienestar general de la comunidad es el fin que persigue Mercado en toda su obra. Puesto que la convivencia de los hombres en comunidad se basa en la ayuda mutua para mejor satisfacer las necesidades, es menester observar la regla de oro $\mathrm{y}$, por tanto, que unos no agravien a otros en sus relaciones y tratos. De ahí proviene el considerar que los intercambios y los contratos deben ser equilibrados y equiparables las prestaciones y las contraprestaciones. La gran dificultad estriba en saber igualar cosas que por naturaleza son disimiles, pero que, no obstante pueden representar una estima equivalente para las personas que establecen el trato.

La equivalencia de las cosas puede facilitarse mediante el establecimiento de un precio justo. Más éste no puede ser un término fijo, inamovible tanto en el tiempo como en el espacio. Ni siquiera en un mismo tiempo y lugar puede establecerse por lo general un único precio que sea el justo; más bien es un precio flexible que admite límites, máximo y mínimo.

\footnotetext{
${ }^{17}$ Ostentar la riqueza suele exacerbar el ánimo del pueblo llano y hacerlo de balde no es éticamente aconsejable, porque induce a la criminalidad entre la gente menesterosa, y no digamos entre la vil. Ya lo decía el poeta romano-bilbilitano: «Corano me debe cien mil sestercios y Mancino doscientos mil, Tito trescientos mil, Albino el doble, un millón Sabino y otro Serrano, de los inmuebles y las fincas me vienen tres millones completos, de los rebaños de Parma seiscientos mil. Todos los días, Afro, me cuentas esto y retengo estos datos mejor que mi nombre. Conviene que me des algún dinero para que pueda soportarlo: compensa mi náusea de todos los días con monedas: no puedo, Afro, oír todo esto gratis». (Marcial, Marco Valerio Marcial: Epigramas completos, Madrid, Ediciones Cátedra, 2011 (Lib. IV,37).
} 
Por otra parte no se debe olvidar que el hombre y su familia requieren vivir, para lo cual precisa un salario acorde con su especialización en el trabajo. Por ende, una cosa que se obtiene para luego intercambiarla no puede tener el mismo precio de adquisición que el posterior de venta.

En resumen, muchas y variadas son las circunstancias y las consideraciones a tener en cuenta en los tratos, para llegar a dilucidar si un precio es justo o no. Por estos motivos, la mayor parte de la obra de Mercado gira en torno del precio justo ya sea en el comercio, en los cambios, o en el uso del dinero, y para su estudio establece una abundante casuística, que concisamente se expone bajo las siguientes rúbricas:

8.1 Precios tasados

Puesto que la finalidad de la república es conseguir el provecho y comodidad de los ciudadanos, sin que nadie salga perjudicado, una de las principales funciones del príncipe (como cabeza de toda la comunidad) es procurar que cada cosa se venda por lo que realmente vale, ya que «es un dictamen natural de la razón» (p.160).

En las cosas indispensables para la vida no conviene que el mercader determine el precio, «Por que dejarlo a su voluntad es tanto como permitirle robar a la comunidad. Que sabiendo la necesidad que todos tienen de comprar dél no hay fiera, que tanto haga daño en el campo, cuanto hacen éstos en la ciudad, y sus vecinos, subiendo los precios hasta las nubes» (p.157-158). Si la naturaleza no pone precio a las cosas, el oficio de la república «es suplir con sus ordenaciones, lo que la naturaleza falta [...]. Por lo demás es muy justo aprecie, tase ella los bastimentos, y las demás cosas venales. Siendo tan necesario haya de ellas tasa: y no habiéndola puesto la naturaleza» (p.160).

Mercado (p.162) había considerado que: «el justo precio que vamos rastreando, es en dos maneras (como dice el filósofo en el .5. De las Eticas), uno legal, que pone y señala la república, otro natural o accidental, que es el que el uso introduce, y lo que agora vale en plazas, o en las tiendas». Como muchos mercaderes creían que a ellos les correspondía la fijación del precio, Mercado hace ver que el precio justo es el determinado por la estimación popular, que la autoridad de todos los vecinos reside en la república (cuyo fin es el beneficio general) y que si el mercader se considera, autoridad para establecer el precio, siendo él uno solo, mucho mayor autoridad y razón tendrían todos los vecinos juntos para dilucidar el precio justo (p.160). Puesto que el fin del príncipe, es el bien público, y el del mercader el suyo particular, es obvio que la fijación del precio de los artículos muy necesarios para la vida mediante su tasación legal obedece a la ley natural. El juicio de Mercado (p.162) al respecto es: «cada uno es amigo de ese interés, en especial que el fin y deseo destos señores es enriquecer, y su codicia grande, y servirá por estas razones muy contra razón el precio, si en su mano se deja. Así que es justo y muy necesario, que las que más a la vida sirven y se gastan, se evalúen por la república. Las demás se dejen al suceso del tiempo».

Mercado (p.167) prosigue: «Digo que en las mercaderías necesarias se ha de tener respeto principalmente al bien común, y también secundariamente, a la ganancia de los mercaderes: para que con el cebo del interés, y gusto, insistan, y trabajen mejor en proveer la ciudad». Por eso en la fijación del precio legal, estima Mercado (p. 167): 
«Débese considerar lo que a ellos les cuesta, las costas que hacen en traerlo, el riesgo a que lo exponen, por mar o por tierra, el tiempo que tienen ocupado en ellos su dinero, hasta que se saca, ya junto esto, añadiendo un moderado interés se hallará, y pondrá el precio justo».

El precio legal obliga a todos y tiene la mayor fuerza y virtud, «y ata a todos en un punto señalando un cierto término, del cual adelante no se puede nadie extender», según comenta Mercado (p.161). Además, expone Mercado (p.162-163):

Cuando hay tasa, no puede llevar el vendedor, ni un solo ceutí más, y si lo lleva lo ha de restituir [...]. Aunque bien podrá llevar menos que lo que está puesto, y el mercante dárselo, si la pragmática expresamente no dice lo contrario. Porque el intento de la república en evaluar la ropa, es, ir a la mano a la codicia del que vende, mas no impide la ventura del que compra, si por menos pudiere comprarla [...]. Y porque éste punto es uno de los principales desta materia, conviene a saber, que es general obligación en todos guardar la tasa de la república, querría se entendiese, que es más verdadera esta doctrina de lo que pensamos, fundada en piedra firme.

Pero el que los precios estén establecidos por ley no significa que deban ser inmutables; tienen que acomodarse, como dice Mercado (p.166) a «los nuevos sucesos y variedades, que por momentos se recrecen y contemporizasen [...] Estas tasas, lo primero no deben ser perpetuas: si no mudables, según el tiempo, y circunstancias se ofrecieren [...] porque [...] las leyes se han de acomodar al tiempo, y disposición de la república».

8.2 Precios libres

Mercado deja al mercado libre la fijación de los precios de las mercancías que no sean indispensables para la vida. Al precio libre, Mercado lo ha llamado natural o accidental y luego también lo denomina común. Este precio se diferencia del legal en que no es fijo, ésta expuesto a fluctuaciones debido a múltiples circunstancias que concurren en los mercados. Tampoco se puede decir con exactitud cuál es el precio justo, porque los teólogos lo consideran con flexibilidad: «En este precio común, tiene lugar aquella distinción tan trillada de los doctores que, uno es piadoso, otro mediano, otro riguroso» (p.163). Mercado llama «latitud» a este margen entre el precio mínimo y máximo, y es «todo justo» (p.163). Los extremos de esta latitud pueden aplicarse a las ventas al por mayor y a las ventas al detalle (p.212), así como a las ventas al contado o al fiado (p.224).

El precio justo es, pues, para Mercado (p.177), el que se establece en mercados de competencia perfecta; «es el que corre de contado públicamente, y se usa esta semana, y esta hora como dicen en la plaza, no habiendo en ello fuerza, ni engaño, aunque es más variable (según la experiencia enseña) que el viento».

El engaño puede existir de dos formas, según Mercado (p.177-184): Una, en la mercadería si está viciada al tener algún defecto oculto o no. Cualquier defecto es causa suficiente para que el precio sea menor y se tenga que restituir la diferencia en caso de haberse cobrado el precio correspondiente a la mercancía sin defecto, aunque el vicio no fuera conocido por el vendedor. Mercado incluye también en esta categoría el defecto en la cantidad (y no sólo en la calidad) de la mercancía debido al uso de pesas falsas. El 
vendedor, si conoce un vicio oculto, tiene obligación de hacérselo saber al comprador, además de rebajar el precio. Y si el vicio es visible, por ejemplo cuando "el caballo es tuerto, o el negro cojo" (p. 179), es suficiente con la rebaja del precio, ya que el comprador por si mismo puede darse cuenta del defecto.

La otra forma de engaño contemplada por Mercado (p.178), estriba en el mercader cuando «ejercita con engaño su arte haciendo monipodio con sus consortes y compañeros: que no se baje [el precio] ${ }^{18} \gg$. La práctica del monopolio no es privativa de los mercaderes; se extiende a todo tipo de gentes que se conciertan para no bajar los precios, como sería el caso de los oficiales (albañiles y canteros), o que se conciertan para comprar a un precio no superior al que acuerden. Así es que Mercado considera incluido en el monopolio cualquier tipo de concierto que impida la puja y licitación tanto por parte de los vendedores como por la de los compradores; por supuesto, el monopolio comprende «los estancos, tan odiosos» (p.157). En cualquier caso sentencia Mercado (p.182), el monopolio es un «vicio abominable, y aborrecible a todo género de gentes, porque es muy perjudicial, tirano dañoso, y por tal condenado por todas leyes». Como se observa, Mercado propugna indirectamente el mercado de libre competencia.

El precio establecido bajo estas condiciones, sin dolo ni fraude ni fuerza, sea barato, mediano, o riguroso, es justo y obliga a todos, aunque en ocasiones el mercader tenga pérdidas (p.200).

Los precios son variables, porque dependen de las circunstancias en las que se desenvuelve el mercado cada día. Así los precios disminuyen (o aumentan, en los casos contrarios), constata Mercado (p.200) si se tiene «gran necesidad de vender, o rogar con su ropa, $[. .$.$] o porque hay abundancia de aquella mercadería, o no muchos mercantes, o$ poco dinero [...]. Pero hablando a la clara, regla es de teólogos, que el andar rogando con la ropa, la envilece, y disminuye su valor». Mercado (p. 201 y 240-241) nos hace reparar que el precio justo es el correspondiente al lugar y el momento en que la mercancía se entrega, porque a partir de ahí la utilidad, el riesgo y la responsabilidad pasan a ser del comprador, aunque en otra parte se concierte o se pague. Esta regla la amplía Mercado (p.217 y 239) tanto para la venta al fiado como para el pago por adelantado.

Una sola excepción contempla Mercado (p. 207) a esta regla general. Y es que si el vendedor reserva su mercancía para un tiempo posterior en que se espera valdrá más y le requieren para venderla ahora que vale menos, haciéndoselo saber al comprador puede exigirle más precio que el actual (en compensación del beneficio esperado o lucrum cessans), pero no tanto como el que se prevé regirá en el futuro, porque el vendedor se ahorra los costes de almacenaje y los riesgos a que está expuesta la mercancía (merma, deterioro, robo etc.).

8.3 Precios en almoneda

${ }^{18}$ En realidad se trata de oligopolio, pero este término, aunque utilizado por Tomás Moro [1516]: Utopía, Madrid, Ediciones Rialp, 1989, no fue empleado por ningún autor hasta principios del siglo XX. 
Almoneda es la venta realizada en pública subasta, por lo que, en principio, si no hay vicios, el precio de remate es el precio justo, tanto si por haber puja al alza el precio es mayor que el de mercado, como si por falta de licitación el precio es menor (p.209-210). No obstante, la venta en almoneda no está exenta de vicios, bien sean ocultos y no conocidos en el momento de la subasta, bien sean por conciertos entre los licitadores, o bien por sobornos a los subastadores. En todos estos casos la venta es ilícita y son reclamables los daños ante la magistratura (p.210-212).

Por tanto, también en este modo de vender se precisa dilucidar cuál es el precio justo. La regla general, dice Mercado (p.212), puesto que se trata de una venta pública, oficiada por oficiales gubernamentales, debe ser el que la justicia y la ley civil admite. Es decir, el precio que no rebase los límites en más o en menos del $50 \%$ respecto a la latitud del precio del libre mercado. Éste, como se ha visto en el epígrafe anterior, admite un cierto margen, aunque estrecho, entre el precio riguroso y el piadoso que es la latitud. En el presente caso el de la venta en almoneda, el margen del precio justo es mucho más amplio, y así debe ser, porque está de acuerdo con la flexibilidad propia de este modo de vender, en comparación con el modo de vender en el mercado libre, de mucha menor flexibilidad, y por supuesto, con el modo rígido de vender a tasa fijada por ley mientras no varíen las circunstancias (p.212-213).

Aún queda un problema por resolver en lo concerniente a las ventas en almoneda. Se trata de a quién pertenecen los frutos y rentas pendientes de recoger en el momento de la venta de un bien raíz. Mercado (p.214-216) distingue dos casos cuyas soluciones son diferentes. El primero es cuando los frutos o las rentas se generan continuamente; en este caso al vendedor le corresponden las rentas o frutos hasta el momento de la entrega de la posesión del bien raíz y al comprador desde ese momento. Por tanto, el vendedor tendrá que entregar al comprador la parte proporcional de lo cobrado anticipadamente; y al revés, el comprador deberá entregar al vendedor la parte proporcional de lo que esté pendiente de cobrar. El segundo es cuando los frutos o las rentas se generen discontinuamente por períodos; en este caso los gastos efectuados los soporta siempre el vendedor. Pero las rentas o los frutos serán por general del comprador, excepto cuando materialmente se haya recogido parte o todo el fruto antes de la entrega de la posesión del bien raíz que lo generó. Por tanto si la renta estuviera cobrada previamente por tratarse de bienes raíces arrendados, tendrá que entregarse al comprador la renta anticipada cuando la venta se hiciere antes de la recogida del fruto.

Debe quedar claro que toda la disquisición anterior es aplicable cuando en la venta no hubo concierto previo sobre los frutos o las rentas, porque en caso contrario se estará a lo que las partes hubieran acordado. Con lo cual Mercado, si no hay dolo ni fuerza, nuevamente pone de manifiesto la primacía del principio de la libertad para concertar los tratos y contratos.

8. LA TRIBUTACIÓN

Mercado (p. 173) considera lo más natural que los vasallos paguen los tributos a sus 
príncipes y señores, porque con ello se cumple la recomendación del evangelio ${ }^{19}$. Además, Mercado (p. 469) justifica que los pechos y tributos los vasallos a sus príncipes "no los dan de balde, sino bien debidos por bastantes causas y títulos". A continuación explica por qué los impuestos no son de balde y expone la finalidad de la tributación; a saber: los reyes incurren en muchas obligaciones con sus vasallos, pues deben regirlos en paz y conservarlos a salvo de los enemigos. El cumplimiento de estos objetivos requiere incurrir en gastos, como el pago a los jueces, gobernadores, oficiales $\mathrm{y}$ resto de funcionarios, entre ellos los soldados y marineros de las fuerzas armadas (terrestres y navales).

Siendo muy simples las apreciaciones de Mercado sobre el gravamen fiscal, lo más destacable es que defiende una imposición moderada. Mercado (p. 291) recurre, como máxima, a la paradoja de Hesíodo (p.291): "la mitad es más que el todo"; luego la explica y aplica a los tributos (p. 292): "los príncipes y señores, que ponen pechos y tributos, a sus vasallos [...] han y deben entender, que la mitad de los que ellos querrían, les será siempre más y mejor, que el todo".

9. LOS INSTRUMENTOS ANALÍTICOS

El asunto principal de esta obra de Tomás de Mercado es dilucidar cuál es el precio justo de las mercancías, de los cambios y de las usuras; ahora bien, sus razonamientos se basan implícitamente en unos principios. Estos principios, o instrumentos analíticos, tienen gran interés, porque, transcurrido el tiempo, pasarían a ser fundamentos del análisis teórico de la ciencia económica. A continuación se exponen algunos de los más relevantes:

10.1. Principio de las ventajas absolutas

Este principio, consistente en comprar barato y vender caro, constituye el fundamento del comercio, aunque en realidad obedece a una característica psicológica común a todos los hombres en sus tratos y contratos. Su origen se puede rastrear, aun cuando no expresado con mucha claridad, hasta Aristóteles ${ }^{20} \mathrm{y}$ aun antes hasta Jenofonte ${ }^{21}$.

Mercado (p.155) lo enuncia el modo siguiente: «El deseo del mercader es el universal de todos, aunque como dice San Agustín, es con toda su generalidad vicioso, conviene a saber, querer mercar barato, y vender caro, y tiene más el tratante: que no solamente lo desea y apetece sino lo ejercita y procura».

10.2. Teoría subjetiva del valor

Esta teoría es otro de esos principios que sirve para fundamentar al valor de las cosas y que también obedece a la psicología de las personas. La teoría subjetiva del valor tiene

19 "Dad al César lo que es del César" (Mt. 22:21; Mc. 12:17; Lc. 20:25).

${ }^{20}$ Aristóteles. La Política, Barcelona: Editorial Iberia, 1967 (Lib. I cap III,15, p.20): «la experiencia introdujo más arte cuando se supo mejor donde convenía tomar, los objetos de cambio y lo que había de hacerse para obtener mayores ganancias».

${ }^{21}$ Jeneofonte: Económico, edición bilingüe traducción y notas de Juan Gil, Madrid: Sociedad de Estudios y Publicaciones, 1967 (XX,27 y 28, p. 428): «Los comerciantes [... acuden] por el trigo, doquiera más abunde, allí navegan en su busca surcando el mar [...]. Y cuando se ven en precisión de dinero no se deshacen se él en cualquier lugar y a la buena ventura, sino que, doquiera tenga el trigo un valor más alto y de mayor estima goce, allí lo llevan para entregarlo a sus habitantes". 
su origen en las apreciaciones de Sócrates, transmitidas por Jenofonte (1967: 270), según las cuales el valor de los bienes es un atributo conferido a los objetos por las personas mediante su apreciación subjetiva, y no es, por tanto, una característica objetiva e intrínseca de las $\operatorname{cosas}^{22}$. La consideración de Mercado (p.158) sobre esto es: Dice Aristóteles admirablemente, en el .5. de las Éticas, que lo que da valor y precio a todas las cosas terrestres, es nuestra necesidad. Que si no las hubiésemos menester, no las mercarían ni apreciarían. Esta es la medida y peso de su valor. No se estiman en más de lo que sirven: y aquellas se tienen en más: que son más necesarias y que más aprovechan [...]. En ninguna parte, en ninguna nación, se apreció jamás cosas según su natural: sino por nuestra necesidad: y uso.

Para la mejor compresión de este principio refiere Mercado (p.159) lo sucedido con el oro de una flota española que en 1556 naufragó en la costa americana de la Florida. Por ser muy sabroso el relato se transcribe a continuación:

Notable historia y digna de perpetua memoria es lo que acaeció el año de cincuenta y seis, a la flota de Nueva España, que allí se perdió. Que habiendo ya encallado los navíos con la fuerza del agua y viento, y sacado el tesoro, y tendido en la playa (que eran ochocientos mil ducados) daban dellos los Españoles, y ofrecían a los Indios cuanto quisiesen, así por aplacarlos, como por bastimentos. De lo cual los Indios se reían en extremo. Y llegaban con una navaja, sin que nadie se lo contradijese al talegón, que traía mil, y dos mil ducados, y abriéndolo, vaciaban los reales por el suelo como si fuera polvo, y con sólo el cañamazo, y lienzo de las partidas, iban tan contentos, que huían con él por sus arenales y páramos, como gamos, pensando que habían de ir tras ellos a quitárselo. De que los nuestros también reían no poco.

Y lo que más de admirar, que se lo dejaron allí todo en la playa y caminaron por tierra a México, donde llegados dieron aviso al Visorey don Luis de Velasco, y envió al capitán Villafaña con dos o tres carabelas, do hallaron toda la plata tendida, y esparcida por la playa (a cabo de cuatro o cinco meses que la habían dejado entre tantos Indios) mas cabal y segura, que si la hubieran puesto muy en cobro. Y como los Indios vieron venir las carabelas, y saltar la gente en tierra, y embarcar la plata, y embarcada volverse quedaron admirados, se hubiesen puesto en camino tan largo del mar, por una cosa tan astrosa. Esta moneda vino luego el año siguiente, a esta contratación, y se repartió a sus dueños. Yo no he leído en todas las antigüedades caso más notable, y espantoso, que se hubiese quedado cuasi un millón de oro tantos tiempos paseándose cada día entre ello los Indios, y que no se bajasen a tomar cosa: solo por un puro y fino menosprecio dello. Esta es prueba evidente desta verdad que tratábamos, que no valen las cosas entre los hombres, lo que vale su natural, sino según dijo el filósofo, lo que es nuestra voluntad y necesidad, como la que les da estima y valor.

10.3. La escasez relativa

No obstante, Tomás de Mercado matiza el principio subjetivo precedente con otros de

22 Jeneofonte: Económico, Madrid: Sociedad de Estudios y Publicaciones, 1967 (I,1012 p. 270). 
carácter objetivo, e independientes de la voluntad de las personas. Uno de ellos es la escasez relativa de los bienes que también tiene una influencia en el precio justo.

Este principio, en lo que al precio de los bienes concierne, es contemplado por Mercado (p.168 y 200) en un triple aspecto, cada uno de los cuales influye en el precio:

$1^{\circ}$. Que en el mercado haya muchas o pocas mercaderías.

$2^{\circ}$. Que al mercado acudan muchas o pocos compradores.

$3^{\circ}$. Que haya mucho o poco dinero en circulación.

En otro contexto Mercado (p.182-183) señala una nueva causa que provoca escasez relativa de mercancías: que haya pocos vendedores en el mercado. Es decir, que haya monopolio [u oligopolio]. Pero en este caso ya no se trata de una circunstancia objetiva, sino subjetiva puesto que son los comerciantes, o los artesanos, o los oficiales (como los albañiles y canteros) quienes se conciertan para no bajar los precios.

Podemos concluir que cuando el precio se forma libremente, sin fuerza ni engaño, ya sea en la mercancía (que no debe tener defectos) o ya sea en los mercaderes (que no deben confabularse con otros), la teoría de Tomás de Mercado es equivalente a la moderna teoría de la oferta y la demanda en competencia perfecta (que se basa en la utilidad y la escasez relativa).

Resumiendo: Por un lado «la venta ha de ser libre de entrambas partes» (p.179). Y por otro lado el «precio justo es el que corre de contado públicamente» (p.177), el establecido por el «vulgo sin cabeza [al] apreciar cualquier mercancía» (p.160), «según él común juicio, y estimación de la gente» (p.214). En fin, como dice Mercado (p.201), un precio establecido pública y libremente: «Especialmente si hay otros, que lo saben, y lo pueden comprar, aquello es por entonces su justo valor». Como se ve, se trata de mercados públicos donde la gente está informada y puede pujar, con conocimiento de causa y libertad, si lo desea.

\subsection{Teoría objetiva del valor}

En determinadas circunstancias, Mercado (p.167) asume una concepción objetiva del valor aplicable cuando los precios sean tasados por la ley. En este caso, el precio tiene que cubrir los costes de producción y la ganancia (moderada) de los mercaderes, para estimularles en su trabajo a proveer de abastecimientos a la república: «para qué con el cebo del interés, y gusto, insistan, y trabajen mejor en proveer la ciudad». Un poco más adelante Mercado (p.167) cita cuáles son esos costes de producción:

Débese considerar lo que a ellos les cuesta, las costas que hacen en traerlo, el riesgo a que lo exponen, por mar o por tierra, el tiempo que tienen ocupado en ello su dinero, hasta que se saca, ya junto esto, añadiendo un moderado interés, se hallará, y pondrá el precio justo. Lo cual aunque parece verificarse solamente en la ropa, que viene de fuera: proporcionadamente se puede aplicar en los frutos, y cosecha de la tierra: que también tienen sus gastos, y peligros. Mirar lo que cuestan los peones, la tierra, los pastos, y los demás gastos que se hacen, y darles sobre esto algún interés a los labradores y pastores, pues es ganancia de todos, y bien universal que ellos ganen.

10.5. Elasticidad y gasto del consumidor

La elasticidad es un concepto técnico para medir el grado de sensibilidad de una 
variable ante los cambios de otra; concretamente es el cociente de la variación proporcional de una variable con respecto a la alteración proporcional de otra. Si el cociente es superior a uno, la variable del numerador es elástica respecto a la segunda y si es inferior a uno es rígida. Aplicado el concepto al consumo de bienes objeto de compraventa, la elasticidad está relacionada con el gasto del consumidor, de forma que en los bienes de demanda rígida un aumento del precio hace que disminuye la cantidad demandada, pero al hacerlo en menor proporción que la de la subida del precio, provoca un aumento del gasto (o sea, un incremento de los ingresos del vendedor).

El caso de la elasticidad rígida de los bienes muy necesarios, los que más sirven y se gastan, es el expuesto por Mercado, aunque no enuncia el principio analítico. Para él la subida del precio de estos bienes, como pan, vino, carne, pescado, fruta, etc., enriquece al vendedor en perjuicio del consumidor, pues, en su razonamiento queda implícito, que éste, después de subir el precio, gasta más dinero que antes a la vez que obtiene menos cantidad del producto que compra; de ahí que Mercado (p.157) defienda la tasación legal del precio de esos artículos, para evitar que la gran masa de la población resulte damnificada si se deja la fijación del precio al arbitrio del mercader.

10.6. Naturaleza y esencia del dinero; la circulación fructificadora

Aristóteles ya había concebido el dinero como un medio para facilitar el intercambio, siendo así una invención humana para facilitar las compras y las ventas mediante el establecimiento de un valor cifrado en su equivalencia referida a dos metales, el oro y la plata $^{23}$. A este respecto, sigue Mercado (p.130) al Estagirita y dice: «E inventaron el mercar, y vender por su justo precio, apreciando, y evaluando cada cosa por sí, según qué podía servir al hombre. Y hicieron precio común y general de todas la plata y oro». En estas consideraciones se pueden reconocer dos funciones del dinero: la de servir de intermediario en los intercambios y la de constituir la unidad de medida del valor de las cosas. Mercado (p.131) añade:

Y por lo uno y lo otro acordaron los hombres de escoger un par de metales que fuesen precio de todo lo vendible, para que en poco bulto y tomo, se pudiese llevar el valor de mucho, y entre todos escogieron (como dice Plinio) por muchas y notables razones que trae en el .33. de su natural historia, el oro y la plata. Aunque las principales, a mi juicio son dos, la una, que son más seguros y exentos de peligros, que los otros. Ninguno hay de ellos, que el fuego no lo mude, o lo gaste, o disminuya, sino es el oro, y la plata: que antes lo purifica, limpia y perfecciona. Los segundo, no hay metal que más dure, y más se conserve en cualquier parte que lo pongan, ora en el arca, ora debajo de tierra, ora en el imo y profundo de la mar.

En estas consideraciones, además de volver a tener en cuenta esas dos funciones antes dichas, introduce una nueva: la de servir de depósito de valor, pues éste se mantienen a lo largo del tiempo y de las vicisitudes. Precisamente, las peculiares características de estos metales son las que los convierten en idóneos para desempeñar todas estas funciones requeridas al dinero.

\footnotetext{
${ }^{23}$ Aristóteles. La Política, Barcelona: Editorial Iberia, 1967 (Lib, 1º:19-20).
} 
Ahora bien, Mercado no se contentó con esto, sino que, debido a su buen conocimiento de las prácticas mercantiles, supo ver una nueva peculiaridad del dinero que constituye su verdadera esencia: el dinero está hecho para circular y es precisamente su circulación en manos del mercader la que le hace ser fructífero. Dice Mercado (p.324): «Verdad es hablando en común que más vale la moneda en la caja que esperarla. Aunque a muchos, cierto mejor es tenerla ausente, que en ausencia les gana así la apartan de sí, y casi nunca tienen cantidad junta consigo. En llagando la emplean y tornan a cargar». Es como si el dinero quemara las manos del mercader y rápidamente ha de soltarlo retornándolo a la circulación. Insiste en esta idea al decir Mercado (p.435): «mientras cien ducados están al canto del arca, ninguna cosa aprovechan; no son como casa o viñas, que, estándose quedas, fructifican y sirven; es menester se saquen y enajenen para que multipliquen, dándose, cambiando o mercando».

No fue hasta mediados del siglo XVIII cuando un autor, Cantillon, vio claramente que la circulación es lo más característico del dinero y que la intensificación de su ritmo de circulación (o velocidad) equivale al aumento del dinero en circulación ${ }^{24}$; pero esto último no llegó Mercado a exponerlo, ni siquiera a insinuarlo. Lo que sí hizo fue vincular el dinero con el tiempo, de modo que señaló dos grupos de personas en cuanto a la tenencia del dinero (o preferencia por la liquidez) se refiere: las que muestran una inclinación por el presente y las que prefieren el futuro.

\subsection{El tiempo}

El tiempo es empleado por Mercado como instrumento analítico para fundamentar la plusvalía, según se mencionó anteriormente en las ACTIVIDADES ECONÓMICAS. El tiempo como fuente de rendimientos afecta a cualquier actividad productiva y también al préstamo de dinero. Ya se mencionó cómo la producción es un proceso que requiere tiempo para transformar los bienes intermedios en productos terminados (con lo que adquieren más valor). Mercado (p.131) se refiere al trigo que usado como simiente se convierte después de la cosecha en un producto útil para el consumo; o el mosto que se transforma en vino; o la crianza de potros para obtener caballos. La espera es así un elemento primordial de la producción. También lo es para el comerciante, siendo su arte, el saber aguardar con sus mercancías para venderlas en el momento, o en el lugar más oportuno para obtener así mayores ganancias. Ya se ha tenido la oportunidad de observar cómo Mercado (p.167) considera incluida en el coste la retribución del dinero en función del tiempo que esté invertido en el negocio (el cual, en principio, es el comercio, pero, luego, también se incluye a la producción).

10.8. El tipo de interés: teoría del agio

Enmarcado en su consideración del tiempo como factor que origina valor añadido, Mercado (p.218), aunque condene la usura, reconoce que el interés «es precio del esperar la paga» y nos presenta una consideración sobre el tipo de interés que podría

${ }^{24}$ Cantillon, Richard [1755]: Ensayo sobre la naturaleza del comercio en general, México: Fondo de Cultura Económica, 1996 (p. 82 y ss.). 
denominarse teoría del agio, según el apelativo debido a Böhm-Bawerk ${ }^{25}$. Este último eligió tal nomenclatura para designar las teorías sobre el interés basadas en la diferente valoración en dos periodos distintos del tiempo (o traslado en el tiempo), en analogía al verdadero agio, que es la ganancia obtenida por los cambistas, cuya profesión consiste en cambiar unas monedas por otras, es decir, por trasladar en el espacio el dinero (como es en realidad cambiar, por ejemplo, moneda española por la inglesa, siendo la una usada en España y la otra en un lugar diferente tal que el Reino Unido). Ahora bien, Böhm-Bawerk estima que el dinero también puede trasladarse en el tiempo, puesto que la psicología humana aprecia de forma desigual el valor del dinero en el presente y en el futuro. Consideró que uno de los primeros economistas en apreciar esto fue Turgot, pero está claro que no había leído a Tomás de Mercado, ya que éste dos siglos antes ya había explicado ese estado psicológico de los hombres que les inducen a valorar más el dinero en la actualidad que en un tiempo más lejano; dicho con las palabras de Mercado (p.324) «más vale el dinero presente, que el ausente». Y por eso están los hombres dispuestos a pagar una prima en el futuro cuando se devuelve un dinero que, mediante un préstamo, pueden disfrutar hoy mismo, o usar en una empresa productiva. La frase de Mercado (p.324) que resume magistralmente esta teoría suya sobre el tipo de interés, basada en la psicología humana, que con ligeras modificaciones ha pasado al refranero español, es la siguiente: «más vale pájaro en mano, que buitre volando», a lo que añade Mercado (p.324): «más vale el dinero presente que el ausente: el que ya se tiene está seguro, el ausente sujeto a dos mil peligros, que puede ser no paguen o difieran la paga».

No obstante, hay otros individuos, como los banqueros, mercaderes y comerciantes, que demuestran tener una preferencia por el futuro, al desprenderse del dinero actual para recuperarlo con ganancias en un tiempo posterior. Así enuncia Mercado (p.324) esta otra preferencia temporal: «En los negociantes no vale más el dinero presente que el ausente, antes al revés, más el ausente que el presente».

10.9. El valor del dinero: concepción nominalista

Para Mercado, el dinero no se escapa de la general teoría subjetiva del valor, por lo que podemos considerar que este autor, básicamente, tiene una concepción nominalista del dinero; sin embargo, como el dinero en aquella época estaba constituido por los metales preciosos, a la postre sea Mercado, a efectos prácticos, un metalista, pues como apunta Schumpeter: ambas posturas no son incompatibles ${ }^{26}$. Mercado, como todos los escolásticos, se opone a las adulteraciones monetarias (en ley y peso) que rebajan el valor extrínseco de las monedas: «La libra, el arroba y otras pesas desta jaez miden en ellas la cantidad, mas el dinero mide su valor y precio: oficio muy principal. Y es regla universal, y necesaria que ha de ser cualquier medida fija, cierta, y permanente» (p.

25 Böhm-Bawerk, Eugene [1884]: Capital e interés, México: Fondo de Cultura Económica, $2^{a}$ edición, 1986 (p. 279, nota 25).

${ }^{26}$ Schumpeter, Joseph Alois [1954]: Historia del Análisis Económico, Barcelona, Ediciones Ariel, 1971 (p. 336). 
265). «Porque bajar, y subir la moneda, es aumentar, o disminuir la hacienda de todos, que toda últimamente es dinero, y en resolución es mudarlo todo» (p.265).

Ahora bien, el oro y la plata, en realidad, no tienen demasiada utilidad práctica para la vida humana (salvo la de la ostentación, la cual no aprovecha para que el común de la gente sobreviva) y si esos metales tienen valor (se debe entender valor nominal) por su utilidad de facilitar el intercambio es porque la república se lo otorga, como así explica Mercado (p.158):

$\mathrm{Al}$ oro y la plata [...] les dio la república tanto ser y valor que los hizo valor y precio de todas las cosas; al contrario un caballo, y un buey, que si se mira su natural y esencia, vale otro tanto cuerpo de oro, por ser vivo, y le excede sin comparación, no tiene tanta estima y sería dislate tenerla. Porque no se ha de estimar una cosa en más de cuánto conduce a nuestra sustentación.

En prueba de que el valor de los metales preciosos depende de la estima y aprecio subjetivo que de ellos tiene la gente, además del relato antes trascrito sobre el naufragio de la flota que transportaba oro, Mercado (p.158-159) añade:

Do la mayor alcanzó en tiempos de su gentilidad fue en Perú y Nueva España: y no llegó a más de ser una joya y gala, como acá un plumaje: no precio de las cosas ni moneda. En la Florida que es tan grande como toda Europa, tienen en tan poco el oro y la plata, que así se desdeñan de tomarlo, como nosotros la tierra: el cobre, y hierro es entre ellos suma riqueza. Y quieren más una libra de cobre que cuatro de oro. Dice en que con aquello labran, y cultivan la tierra: que los sustenta, y produce frutos. Cierto no hay, ni he leído de gente (en esto), más acertada.

Y también dice Mercado (p.160):

Ingenio humano fue el comprar y vender. E invención de los hombres hacer el oro y plata, precio de lo restante. Pues si la naturaleza no tasa cuánto han de valor, cuántos reales, cuántos ducados: a quien más conforme a razón pertenecerá proveer esto, siendo tan necesario, que a la república. Cuyo oficio es suplir con sus ordenaciones, lo que la naturaleza falta.

En definitiva, el dinero es un bien económico peculiar en cuanto sirve para facilitar el intercambio, aunque no indispensable porque cualquier mercancía puede ser trocada por otra. También hay que tener en cuenta que la Naturaleza no estableció los precios ni el valor nominal de las monedas, el cual es fijado subjetivamente por las repúblicas que deben mantenerlo estable, pero, pese a ello, en su poder adquisitivo o capacidad de trueque, no deja de ser una mercancía más y como tal sujeta a la teoría subjetiva del valor, y, simultáneamente, a la objetiva en cuanto a su escasez y abundancia relativa se refiere.

10.10. El poder adquisitivo del dinero: teorema de la cantidad

El poder de compra del dinero es una cuestión distinta de su valor nominal. Una misma moneda compra más o menos mercancía según diversas circunstancias, entre ellas que haya poco o mucho dinero en circulación, pues como observa Mercado (p.168): «Vemos en las ferias, que si hay mucha ropa, vale barato; si pocos compradores, más barato; si hay poca moneda vale de balde, y se quema. Al contrario, haber poca ropa la hace tener 
estima; si hay muchos que compren, crece, y más si hay abundancia de dineros».

Como se aprecia para Mercado el poder adquisitivo del dinero está vinculado a su cantidad en circulación, de modo que aquél es inversamente proporcional a ésta. Según Mercado (p.329) «lo que hace bajar, o subir la plaza es la abundancia o penuria de la plata, si hay mucha, andan bajos los cambios, si poca crecen, y está claro, que la abundancia, o falta, causan se estime en mucho, o se tenga en poco». Esta apreciación constituye, según nomenclatura de Schumpeter (1971:362), el Teorema de la Cantidad, que es un importante paso hacia la moderna teoría cuantitativa del dinero. 